\title{
The Relationship between Culture Shock and Self-Esteem of New Students Outside Java Island at University of Jember
}

\section{'Ami Allaili Wahidah', Erti Ikhtiarini Dewi2², Enggal Hadi Kurniyawan³}

\author{
${ }^{1}$ Nursing Science Study Program, Faculty of Nursing, University of Jember \\ 2Psychiatric nursing, Faculty of Nursing, University of Jember; erti i.psik@unej.ac.id (Corresponding Author) \\ ${ }_{3}^{3}$ ssychiatric nursing, Faculty Nursing, University of Jember, Indonesia
}

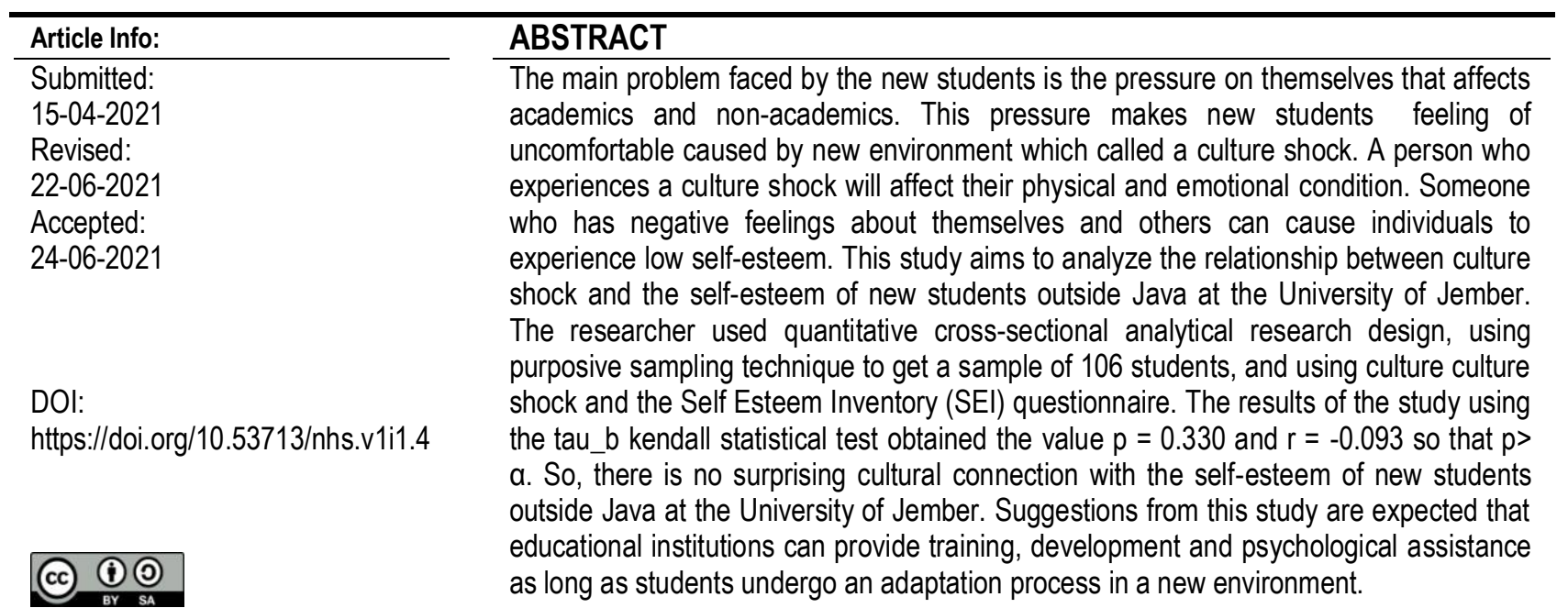

Keywords: new students, culture shock, self-esteem

\section{INTRODUCTION}

Adolescent is someone who experiences a transition period from childhood to adulthood for ages ranging from 10 years to 19 years [1]. Adolescence is a period where individuals can develop themselves regarding knowledge, skills, managing emotions and relating to others. The Regulation of the Minister of Health of the Republic of Indonesia Number 25 of 2014 explains that the age of adolescents starts in the range of 10 to 18 years and according to the Population and Family Planning Agency (BKKBN), the age of adolescents starts from 10 years to 24 years and is not married.[2]. When teenagers at that age began to think for the future, at that time many teenagers were willing to migrate to seek insight, seek the desired and better education, and work for further survival. A teenager who has finished continuing their high school (SMA) will compete to continue their life for a better future, especially students who want to continue their higher education education, in order to continue for the future many teenagers are willing to migrate to the island. others, especially the destination is the island of Java [3].

Java Island is one of the main destinations for students from all over the region to continue their education at public and private universities. Rufaidah's Research [4] stated that Java Island is the most desirable place for students from regions who want to continue their education to higher education because some universities in Java are considered superior compared to others. Data from the Central Statistics Agency (BPS) shows that there are 1,500 universities spread across Java from 3,011 universities in Indonesia. Especially in East Java, from data from the Central Statistics Agency of East Java Province (BPSPJT) there are around 326 private universities and 9 state universities [2]. One of them is the University of Jember. From the results of research studies in 2018, there were 7,240 new students consisting of 2,108 students who were accepted through the National Selection of State Universities (SNMPTN), 2,972 from the SBMPTN pathway, 2,064 from the SBMPTN pathway, 67 from the transfer level pathway, 29 students who came from over level. These new students who come from various regions and cultures in Indonesia who join into one scope or environment that allows cultural contact between students [5].

Jember University is one of the State Universities in East Java which is located in the district of Jember, which is located at the eastern tip of the island of Java. The Jember area is considered the most remote area, but from year to 
year the interest of students to enroll at the University of Jember is increasing and with the same goal, namely to study and continue to a higher level. The more overseas students, the more dynamics that occur. This usually happens because new students have different backgrounds and cultural origins. Jember is an area where the majority of Javanese and Madurese languages are relatively balanced so that the atmosphere of the touch of Javanese-Maduran culture can be felt, especially in urban areas. This very thick blend of Javanese and Madurese cultures is often referred to as Pendalungan or "mixing" [8].

Belford's research [9] explains that students who experience culture shock are students who are required to live independently socially and academically in a new environment or in a foreign environment, and they find cultural norms that are not well known in the social and educational fields. Based on the results of research conducted by Umayyah [10] explained that culture shock was very influential on the adaptation of students, especially those from outside Java because they felt uncomfortable in a new place, so that the individual felt alienated. The research was supported by Burns in Sari [11] explains that individuals will have difficulty expressing themselves, their feelings and thoughts. The reason is that there is a negative assessment of oneself and others. These negative assessments can cause individuals to have low self-esteem, including first-year students who have negative feelings towards themselves and others, feel less confident and have negative judgments from people around them, this makes students less confident. Therefore, students must be able to know their level of ability in order to evaluate the potential that exists within themselves by carrying out a self-assessment process or called Self [12].

Self-esteem is a condition in which individuals are able to assess themselves in carrying out the processes of daily life. Coopersmith Research in Haqi [13] explains that self-respect is a very important thing in one's life. Respecting yourself does not mean exalting yourself and looking down on others and vice versa. Therefore, immigrant students need to adapt to their new environment. Not infrequently, in the first months these overseas students feel they have failed to adjust, are bored, uncomfortable with the conditions in their new place, as a result they experience culture shock, panic, anxiety, loss of confidence, reduced body resistance so that they are susceptible to disease [5]. Finally, causing a reaction to want to return to his hometown which can disrupt the concentration of the lecture process as the main goal of wandering. The research conducted there are 72 respondents, $45.83 \%$ have high self-esteem and $45.84 \%$ have high self-adjustment [14]. This shows that there is a relationship between self-esteem and adjustment in college for new students.

Based on the explanation above, the researcher wants to do further research in order to get a finding that is useful, especially for the nursing profession, namely to develop professionalism, especially regarding culture shock and self-esteem of new students. Based on this description, researchers want to know the relationship between culture shock and self-esteem of new students outside Java. at the University of Jember.

\section{METHOD}

This research is included in the type of descriptive analytic research with a cross sectional approach. The population in this study were 214 new students outside Java at the University of Jember. The sampling technique uses a purposive sampling technique, with a sample of 106 respondents with inclusion criteria, namely new immigrant students entering the 2018 academic year at the University of Jember, coming from outside Java and Madura, never living in Java and Madura, Willing to be research respondents, and with the exclusion criteria of living with relatives or family in Jember since the beginning of entering lectures, D3 students who continue S1 at the University of Jember. The data collection tool uses a questionnaire that has been tested for validity. Data were analyzed using the Chi Square test to determine the relationship between culture shock and self-esteem for new students outside Java at the University of Jember. Research data was taken using a research approval sheet (Informed Consent), confidentiality (Confidentiality), Beneficience (Principle of benefit), fairness (Justice), and anonymous (Anonymity) and conducted an ethical test to the faculty of dentistry with no.226/UN25.8/KEPK/DL/2018.

\section{RESULT}

The research results are presented in the form of narratives and tables. Research data is divided into two, namely general data and special data. General data contains the results of univariate analysis of the characteristics of the research sample, namely age, gender, faculty, and regional origin. Specific data consisted of research variables, namely cultural shock and self-esteem of new students outside Java at the University of Jember. 


\section{Univariate Analysis}

Table 1. Age of New Students Outside Java at the University of Jember in December 2018 (n:106).

\begin{tabular}{ccc}
\hline Variable & Median & Min-Max \\
\hline Age (years) & 18.00 & $17-22$ \\
\hline
\end{tabular}

Table 1 shows the median age of new students outside Java Island is 18.00 years with the youngest age 17 years and the oldest age 22 years.

Table 2. Gender, Faculty, and Regional Origin of New Students Outside Java at the University of Jember in December 2018 (n:106)

\begin{tabular}{|c|c|c|}
\hline & frequency & Percentage (\%) \\
\hline \multicolumn{3}{|l|}{ Gender } \\
\hline Male & 33 & 31.1 \\
\hline Female & 73 & 68.9 \\
\hline \multicolumn{3}{|l|}{ Faculty } \\
\hline Teaching Science & 11 & 10.4 \\
\hline Economiics and Business & 9 & 8.5 \\
\hline Engineering & 9 & 8.5 \\
\hline Social Science and political Science & 6 & 5.7 \\
\hline Agriculture & 8 & 7.5 \\
\hline Law & 12 & 11.3 \\
\hline Culture Studies & 7 & 6.6 \\
\hline Computer science & 10 & 9.4 \\
\hline Math and Science & 3 & 2.8 \\
\hline Agricultural Technology & 3 & 2.8 \\
\hline Nursing & 6 & 5.7 \\
\hline Public Health & 1 & 0.9 \\
\hline Pharmacy & 6 & 5.7 \\
\hline Dentistry & 10 & 9.4 \\
\hline Medical & 5 & 4.7 \\
\hline \multicolumn{3}{|l|}{ Origin } \\
\hline West Papua & 7 & 6.6 \\
\hline Central Papua & 3 & 2.8 \\
\hline East Kalimantan & 14 & 13.2 \\
\hline Maluku & 3 & 2.8 \\
\hline North Sumatera & 21 & 19.8 \\
\hline Papua Merauke & 1 & 0.9 \\
\hline Bali & 12 & 11.3 \\
\hline NTT & 2 & 1.9 \\
\hline Lampung & 10 & 9.4 \\
\hline NTB & 5 & 4.7 \\
\hline Bangka Belitung & 1 & 0.9 \\
\hline North Kalimantan & 2 & 1.9 \\
\hline South Sumatera & 3 & 2.8 \\
\hline Central Kalimantan & 3 & 2.8 \\
\hline Central Sulawesi & 3 & 2.8 \\
\hline Soulth Sulawesi & 2 & 1.9 \\
\hline Jambi & 1 & 0.9 \\
\hline West Kalimantan & 1 & 0.9 \\
\hline D.I Aceh & 1 & 0.9 \\
\hline Riau Island & 6 & 5.7 \\
\hline West Sumatera & 3 & 2.8 \\
\hline Soulth Borneo & 1 & 0.9 \\
\hline Bengkulu & 1 & 0.9 \\
\hline
\end{tabular}

Table 2 shows the gender of new students outside Java Island from 106 dominant female students $(68.9 \%)$. The highest number of respondents based on faculties at the University of Jember was from the law faculty as many as 12 
students $(11.3 \%)$, and the lowest was from the public health faculty respondents, namely 1 student $(0.9 \%)$, and the highest number of respondents by region of origin was from North Sumatra 21 students (19.8\%), and at least 1 student from Papua Merauke, Bangka Belitung, Jambi, West Kalimantan, DI Aceh, South Kalimantan, Bengkulu (0.9\%)

\section{Culture Shock Category}

Table 3. Range of Culture Shock for New Students Outside Java at the University of Jember in December 2018 (n:106)

\begin{tabular}{|c|c|c|c|c|}
\hline Variable & Category & Criteria & frequency & Percentage $(\%)$ \\
\hline \multirow[t]{3}{*}{ Culture Shock } & High & $X \geq 85.17$ & 4 & 3.8 \\
\hline & Medium & $64.83 \leq X<85.17$ & 30 & 28.3 \\
\hline & low & $\mathrm{X}<64.83$ & 72 & 67.9 \\
\hline
\end{tabular}

Table 3 regarding the culture shock variable from 106 respondents, there are 4 respondents with high category shock culture $(3.8 \%)$, totaling 30 respondents experiencing moderate culture shock (28.3\%), totaling 72 respondents experiencing culture shock in the low category (67.9\%).

\section{Self-Esteem Category}

Table 4. Categories of Self-Esteem of New Students Outside Java at the University of Jember in December 2018 (n:106)

\begin{tabular}{|c|c|c|c|c|}
\hline Variable & Category & Criteria & frequency & Percentage (\%) \\
\hline \multirow[t]{3}{*}{ Self Esteem } & High & $X \geq 81.67$ & 92 & 86.8 \\
\hline & Medium & $68.33 \leq X<81.67$ & 14 & 13.2 \\
\hline & low & $X<68.33$ & 0 & 0 \\
\hline
\end{tabular}

Table 4 regarding the self-esteem variable from 106 respondents based on the high category obtained the number of 92 respondents (86.8\%), and the medium category of 14 respondents (13.2\%).

\section{Culture Shock Indicator}

Table 5. Indicators of cultural shock for new students outside Java at the University of Jember in December 2018 (n:106)

\begin{tabular}{lccc}
\hline \multicolumn{1}{c}{ Indicator } & Median & Modus & Min-max \\
\hline Tension due to efforts to adapt psychologically & 11.00 & 11.00 & $6-18$ \\
\hline Feelings of loss and deprivation of family, friends, status, and belonging & 15.00 & 14.00 & $8-46$ \\
\hline Rejection of people in a new environment & 10.00 & 11.00 & $5-18$ \\
\hline $\begin{array}{l}\text { There is confusion about the role, expectations of the role, values held, feelings and } \\
\text { self-identity }\end{array}$ & 12.00 & 7.00 & $6-21$ \\
\hline $\begin{array}{l}\text { Dislikes differences in language, customs, values or norms, manners in the area of } \\
\text { origin and in the new area }\end{array}$ & 5.00 & 6.00 & $3-9$ \\
\hline $\begin{array}{l}\text { Feelings of helplessness caused by not being able to adjust to a new environment } \\
\text { Pele }\end{array}$ & 7.00 & 8.00 & $4-14$ \\
\hline
\end{tabular}

Table 5 shows that the lowest results are that new students do not like differences in language, habits, values or norms, manners in the area of origin and in the new area, the indicator shows a median value of 5.00 , there is a value that often appears 6.00 , The minimum score is 3 and the maximum value is 9 . So, in this indicator the possibility of new students not liking the differences in language, habits, values or norms, politeness in the area of origin and in the new area is very small. 


\section{Self-Esteem Indicator}

Table 6. Self-Esteem Indicators for New Students Outside Java at the University of Jember in December 2018 (n:106)

\begin{tabular}{lcc}
\hline \multicolumn{1}{c}{ Indicator } & Mean & SD \\
\hline Feelings about yourself & 55.95 & 6.14 \\
\hline Feeling towards life & 22.03 & 2.52 \\
\hline Relationships with other people & 13.44 & 1.60 \\
\hline
\end{tabular}

Table 6 regarding the highest self-esteem indicator, namely feelings about oneself, the average result is 55.95 , and for the self-esteem indicator the standard deviation is 6.14 . So that varied results are obtained as described by Santoso [15] if the results of the standard deviation are larger then the data has more variation, whereas if the results of the standard deviation are small, the variations in the data values are more the same. This shows that freshmen's feelings about themselves have a greater variation than feelings about life and relationships with others.

\section{Bivariate Analysis}

Table 7. Results of Bivariate Analysis of Cultural Concussion and Self-Esteem of New Students Outside Java at the University of Jember in December 2018 (n:106)

\begin{tabular}{lccc}
\multicolumn{1}{c}{ Variabel } & $\mathrm{n}$ & $\mathrm{p}$ & $\mathrm{r}$ \\
\hline Culture Shock & 106 & 0.330 & -0.093 \\
\hline Self Esteem & 106 & & \\
\hline
\end{tabular}

Table 7 states that the correlation between culture shock and the self-esteem of new students outside Java at the University of Jember, which consists of 106 students, obtained a $p$ value of 0.330 , then $p>0.01$ which means that there is no relationship between culture shock and the self-esteem of new students outside the island. Java, $r=-0.023$ which means the correlation is weak in the opposite direction. So, the lower the cultural shock that students have, the higher the self-esteem that students have.

\section{DISCUSSION}

\section{Culture shock for new students at the University of Jember}

The results of the study of the cultural shock variable obtained a median value of 59.00 and for the categorization of 106 respondents the results of the high category concussion were 4 students $(3.8 \%)$, for the medium category 30 students $(28.3 \%)$, and for the concussion low category culture amounted to 72 students $(67.9 \%)$. So it can be said that the cultural shock that occurred in new students outside Java at the University of Jember experienced a level of culture shock in the low category.

The same study conducted by Siregar [16] regarding culture shock in Minang students consisting of 100 students contained 71 students in the low culture shock category (71\%). Meanwhile, in the research conducted by Amalia [17], different results were obtained from the researcher, namely from 35 students there were 17 students in the medium category of cultural shock (48.6\%), and Hasibuan's research [7], namely from 85 students, there were $69,4 \%$ fall into the category of moderate level of culture shock, in the study the culture shock that occurred was caused because students had difficulty adjusting to the population in their new environment.

The results of the cultural shock indicator there are the lowest results that new students do not like the differences regarding language, habits, values or norms, manners in the area of origin and in the new area, from several indicators the average score is 5.00 , the minimum value is 3 and the maximum value is 9 . So that in this indicator the possibility of new students not liking the differences in language, customs, values or norms, politeness in the area of origin and in the new area is very small. This is supported by research by Talabessy [18] that the everyday language used by students is Indonesian, because this language is a national language so many understand it even though the accent is from their respective regions. Indonesian is a unified language that has been effectively used as a means of communication for the Indonesian nation so that it is easy to adapt to new environments, especially Indonesia.

Culture shock according to Chaney \& Martin [19] is a wound that appears when a person moves from the original culture to a different culture. culture shock results in a person's inability to adapt, ranging from psychological and 
physiological. This is supported by Andani [20] culture shock is a condition where individuals are not ready to experience changes in cultural values caused by the movement from the original culture to a new culture.

Researchers assume that respondents feel happy when accepted at the University of Jember, from some of the items above the results show that language differences are not something they fear, from these language differences make students feel enjoy in their new environment and the new environment makes them happier, even though some students are not used to it. with the new environment. The way they do to minimize errors in communication is to use Indonesian with an accent from their respective regions. With the presence of several students who experienced culture shock in the high category, nurses and educational institutions could provide guidance regarding the introduction of culture around the University of Jember so that students, especially outside Java, could minimize the occurrence of culture shock.

\section{Self-Esteem of New Students at the University of Jember}

The results of the self-esteem variable obtained an average of 91.48 and for the categorization division of 106 students for the high self-esteem category, the number of students obtained was 92 students (86.8\%), and the medium self-esteem category was 14 students (13.2\%). So, it can be concluded that the self-esteem of new students outside Java at the University of Jember is in the high self-esteem category.

There are several studies on self-esteem with the same results by researchers, namely research conducted by research by Puspita [17], namely from 75 students there are 33 students in the high self-esteem category of $45.83 \%$. While there are several studies with different results, in Ratih's research [21], out of 68 students, there are 48 students in the category of low self-esteem $67.65 \%$, and Khalid [22], from 30 respondents there are 14 people who have moderate self-esteem. $46.7 \%$.

Coopersmith in Susanto [23] states that individuals who have high self-esteem are individuals who have positive acceptance and appreciation, if someone has a moderate category of self-esteem then that person has similarities with high self-esteem, the difference lies in the intensity of self-confidence, but if someone has high selfesteem, the difference lies in the intensity of self-confidence. People with low self-esteem feel less confident in their assessment of themselves and depend on social acceptance in their environment and the person shows the nature of hopelessness, always imagines failure, feels unattractive, afraid of being wrong, sensitive to criticism and difficult to express the desired feelings. This is supported by Sudirman [24] that individuals who have high self-esteem have confidence in their abilities, are realistic in living their lives and are willing to listen and accept the opinions of others, while people who have low self-esteem tend to be more easily influenced by someone else.

There is an indicator of self-esteem with the highest average of 55.95 , namely feelings about oneself, from several statements in the questionnaire obtained some of the most results, namely respondents respect the opinions of friends and other people, respondents feel happy with the life they live and respondents are responsible with what is happening in his life. The researcher assumes that freshmen perform a good ego defense mechanism as described by Candra [25], someone performs ego defense to relieve anxiety, reduce painful feelings, to maintain feelings of worth and self-esteem. Some of these statements, researchers assume that students at the University of Jember are confident in themselves but there are some who have moderate self-esteem so that efforts are needed by nurses to be able to provide assistance, assisted by guardian lecturers so that they can be closer to providing assistance, strengthening and confidence in themselves. new students outside Java at the University of Jember to minimize the occurrence of low selfesteem.

\section{The relationship between culture shock and the self-esteem of new students at the University of Jember}

The results of the bivariate analysis showed that there was no relationship between culture shock and the selfesteem of new students outside Java at the University of Jember with $p$ value 0.330 , and $r$ value $=-0.093$. So, the results obtained are that there is no relationship between culture shock and the self-esteem of new students outside Java at the University of Jember with a weak correlation.

Reisinger [27] states that individuals will experience culture shock if the individual is not able to adapt effectively so that the individual will experience pressure within himself and be unable to interact with others. However, if the individual is able to adapt well, then the individual is easily oriented and develops the skills that exist in himself and with others. This is supported by Siregar's research [16] that the process of adaptation or adjustment is very necessary, especially for students who migrate, if in the process students are not able to adjust to their new environment, it is not uncommon for these students to experience culture shock, which is an uncomfortable feeling marked by feelings of alienation and the difference between the new environment and the old environment.

Kumalasari [28] said that a person will be able to adapt to a new environment more quickly if there is external support, external support, namely support from friends around or commonly called social support. This social support is 
usually in the form of encouragement, attention, appreciation and affection so that there is a positive impact on the individual to become more valuable. This situation will stimulate individuals to more quickly adapt or adjust to their new environment. This is supported by Puspita's research [14] which states that there are several factors such as attitudes, personality, family, culture and social norms that will affect a person's self-esteem. In this study, it was stated that there was a relationship between self-esteem and self-adjustment. If students have self-esteem, the higher the student will adapt to his environment.

Candra [25] individuals make adaptations to face a problem or to meet their life needs, both psycho and social. Adaptations are created to protect their exaggerated sense of self-worth against public embarrassment, so that a person is able to hide their low self-image and maintain the lifestyle they are currently living. This statement is supported by Field [26] explaining that culture shock is a condition of a person experiencing cultural shock so that a person feels less confident, feels worthless, feels afraid and isolated when in a new environment, and at first glance there is no difference between people who experiencing culture shock and not experiencing so it needs to be explored to find out.

The researcher revealed that culture shock and self-esteem of new students outside Java at the University of Jember had no relationship between culture shock and self-esteem. From the results of this study, it should be taken into consideration for educating new students, especially those from outside Java. The education carried out is expected to be able to maintain and reduce culture shock and low self-esteem in new students from outside Java.

\section{CONCLUSION}

Based on the results of the research and discussion above regarding the relationship between culture shock and self-esteem of new students, it can be concluded that there is no relationship between culture shock and self-esteem of new students outside Java at the University of Jember which has a weak correlation.

For educational institutions, namely providing training and self-development, especially for students who come from outside Java to be more familiar with the culture around the University of Jember, as well as assistance for psychological assistance while students undergo the adaptation process in a new environment.

\section{REFERENCES}

Amalia, F. (2015). Pengaruh Strategi Coping Terhadap Culture Shock Pada Mahasiswa Asing Tahun Ajaran Baru 2015/2016 Universitas Islam Negeri Maulana Malik Ibrahim Malang. Thesis. Universitas Islam Negeri Maulana Malik Ibrahim Malang.

Andani, D. (2017). Penyesuaian Diri Mahasiswa Terhadap Culture Shock (Studi Deskriptif Kualitatif Penyesuaian Diri Mahasiswa Sulawesi Selatan di Yogyakarta). Thesis. Fakultas Komunikasi Dan Informatika Universitas Muhammadiyah Surakarta.

Badan Pusat Statistik. (2015). Jumlah Perguruan Tinggi, Mahasiswa, Dan Tenaga Edukatif (Negeri Dan Swasta) di Bawah Kementrian Pendidikan Dan Kebudayaan Menurut Provinsi 2013/2014-2014/2015. (September 2018). https://www.bps.go.id/statictable/2015/09/14/1839/jumlah-perguruan-tinggi-mahasiswa-dan-tenaga-edukatif-negeri-danswasta-di-bawah-kementrian-pendidikan-dan-kebudayaan-menurut-provinsi-2013-2014-2014-2015.

Belford, N. (2017). International Students From Melbourne Describing Their Cross-Cultural Transitions Experiences: Culture Shock, Social Interaction, And Friendship Development. Journal Of International Students, 7(3), 499-521. doi: 10.5281/Zenodo.569941.

Brandan, Y. D. A. (2017). Studi Deskriptif Kuantitatif: Resiliensi Pada Mahasiswa Perantau Tahun Pertama. Thesis. Fakultas Psikologi Universitas Sanata Dharma Yogyakarta.

Candra, I. W. (2017). Psikologi Landasan Keilmuan Praktik Keperawatan Jiwa. Yogyakarta: Andi.

Chaney, L. H. \& Martin, J. S. (2007). Intercultural Business Communication (4th Ed). New Jersey: Prentice- Hall, Inc.

Devinta, M. (2015). Fenomena Culture Shock (Gegar Budaya) Pada Mahasiswa Perantauan di Yogyakarta. Jurnal Pendidikan Sosiologi: Universitas Negeri Yogyakarta.

Erawan, E., \& Kezia, A. S. (2018). Proses Adapatasi Mahasiswa Perantauan Dalam Menghadapi Gegar Budaya (Kasus Adaptasi Mahasiswa Perantauan di Universitas Mulawarman Samarinda). Ejournal IImu Komunikasi, 6(3), 212-225.

Haqi, D. (2012) Pengaruh Pelatihan Pengenalan Diri Terhadap Peningkatan Harga Diri Remaja Kelas VII SMP Negeri 2 Yogyakarta Tahun 2012. Naskah Publikasi. Program Studi IImu Keperawatan Sekolah Tinggi IImu Kesehatan 'Aisyiyah Yogyakarta. (September 2018). http://digilib.unisayogya.ac.id/784/1/gabungan\%20naspub.pdf.

Hasibuan, R. M. W. (2018). Hubungan Antara Interaksi Sosial Dengan Culture Shock Pada Mahasiswa Luar Jawa di Universitas Sebelas Maret Surakarta. Thesis. Program Studi Psikologi Fakultas Kedokteran Universitas Sebelas Maret. https://eprints.uns.ac.id/22730/

K, Nining Dewi. (2017). Hubungan Antara Harga Diri (Self Esteem) Dengan Keterampilan Interpersonal Siswa Kelas X Sma Negeri 3 Kediri Tahun Pelajaran 2016/2017. Skripsi. Universitas Nusantara Persatuan Guru Republik Indonesia Kediri.

Khalid, I. (2011). Pengaruh Self Esteem Dan Dukungan Social Terhadap Optimism Hidup Penderita Hiv/Aids. Skripsi. Fakultas Psikologi Uin Syarif Hidayatullah Jakarta. Serial Online Http://Repository.Uinjkt.Ac.Id/Dspace/Handle/123456789/486 (Agustus 2018). 
Kumalasari, F., \& Ahyani, L. N. (2012). Hubungan Antara Dukungan Sosial Dengan Penyesuaian Diri Remaja di Panti Asuhan. Fakultas Psikologi Universitas Muria Kudus. 1(1).

Neolaka. (2017). Landasan Pendidikan Menuju Perubahan Hidup. Jakarta: Kencana.

Putri, A. S. (2015). Hubungan Antara Berfikir Positif Dengan Harga Diri Pada Mahasiswa Skripsi Fakultas Psikologi Universitas Muhammadiyah Surakarta. Jurnal. Fakultas Psikologi Universitas Muhammadiyah Surakarta.

Puspita, N. (2014). Hubungan Antar Harga Diri Dengan Penyesuaian Diri di Perguruan Tinggi Pada Mahasiswa Baru Angkatan 2014 Fakultas Psikologi Uksw. Final Assignment. Fakultas Psikologi Universitas Kristen Satya Wacana Salatiga. (07 November 2018). http://repository.uksw.edu/bitstream/123456789/9077/2/T1_802010003_Full\%20text.pdf

Reisinger, Y. (2009). Cross-Cultural Differences In Tourist Behaviour. Oxford, UK: Elsevier.

Rufaida, H., \& Kustanti, E. (2017). Hubungan Antara Dukungan Sosial Teman Sebaya Dengan Penyesuaian Diri Pada Mahasiswa Rantau Dari Sumatera Utarad Universitas Diponegoro. Jurnal Empati, 7(3), 217 - 222.

Santoso, S. (2009). Panduan Lengkap Mengenai Statistik Dengan SPSS 17. Jakarta: PT Elex Media Komputindo.

Sari, R. P. (2006). Pengungkapan Diri Mahasiswa Tahun Pertama Universitas Diponegoro Ditinjau Dai Jenis Kelamin Dan Harga Diri. Jurnal Psikologi Universitas Diponegoro, 3(2).

Siregar, A., \& Kustanti, E. (2018). Hubungan Antra Gegar Budaya Dengan Penyesuaian Diri Pada Mahasiwa Bersuku Minang di Universitas Diponegoro. Jurnal Empati, 7(2), 48-65.

Sudirman. (2015). Harga Diri Mahasiswa S-1 Dan S-2 Universitas Muhammadiyah Malang. Magister Sains Psikologi, Program Pasca Sarjana Universitas Muhammadiyah Malang. ISBN: 978-979-796-324-8.

Susanto, A. (2018). Bimbingan Konseling Disekolah Konsep, Teori Dan Aplikasinya. Jakarta: Prenamedia Group.

Talabessy, M., Walandouw, A., \& Londa, J. W. (2015). Proses Adaptasi Mahasiswa Sorong di Kecamatan Malalayang Kota Manado (Studi Pada Mahasiswa Sorong Selatan di Kelurahan Malalayang 1 Kecamatan Malalayang Kota Manado). E-Journal "Acta Diurna", IV(4). https://Media.Neliti.Com/.../94407-ID-Proses-Adaptasi-Mahasiswa-Sorong-Di-Keca.Pdf.

Umayyah, U. (2015). Pengaruh Culture Shock Terhadap Kemampuan Adaptasi Mahasantri Ditinjau Dari Regional (Jawa Dan Non Jawa) Di Ma'had Sunan Ampel Al-'Aly Universitas Islam Negeri Maulana Malik Ibrahim Malang 2014. Thesis. Universitas Zoebazary, M. I. (2017). Orang Pendalungan Penganyam Kebudayaan di Tapal Kuda. Jember: Paguyupan Padalungan Jember.

World Health Organization. (2019). Adolescent Health And Development. (27 January 2019) http://www.searo.who.int/entity/child_adolescent/topics/adolescent_health/en/ 